International Journal of Childhood, Counselling and Special Education (CCSE)

\title{
IPad as a New Educational Technology: A Review of the Literature
}

\author{
Mohammad Ahmad Abdelaziz Al-Zu'bi, ${ }^{1}$ \\ Zarqa University, Jordan
}

Received: $14^{\text {th }}$ Jul 2020 Revised: $30^{\text {h }}$ Jul 2020 Accepted: $19^{\text {th }}$ Aug $2020 \quad$ DOI: https://doi.org/10.31559/CCSE2020.1.1.1

Abstract: The investigation of the effectiveness of the iPad in education is still inadequate due to considering the novelty of iPad in education. This fact is occurring even though the increase of studies that addressed the iPad in education during the last ten years. Therefore, this study examines the effectiveness of iPad in education through review literature on iPad in education. After a review of the literature on the iPad, the results were in three aspects: reading, writing, and mathematics. In addition, the studies that addressed the iPad as an educational tool were confirmed of the positive effects of iPad in education. However, there is a lack of studies has addressed the iPad with thinking skills such as creative and critical thinking, additionally, motivation and learning motivation. Furthermore, the current study was recommended to conduct studies that addressed the iPad with thinking aspects with motivation and learning motivation.

Keywords: iPad; educational technology; Review of Literature.

1 Corresponding author

Mohammad Ahmad Abdelaziz Al-Zu'bi

Assistant Professor, Zarqa University, Zarqa city, Jordan

E-mail:malzubi@zu.edu.jo 
International Journal of Childhood, Counselling, \& Special Education (CCSE), Volume1, Issue: 1 , September: 2020, pp.1-10

\section{Introduction}

Since 2010, the use of iPad as a new educational technology tool at education studies has already increased, this proving the use and effectiveness of using iPad as a new educational technology tool at education.

We live in the Age of technology that has effectiveness in all aspects of life, especially in education. Besides, the number of schools that used the iPad as educational technology is increased. Therefore, we need to know if this tool is considered an ideal tool or not to make sure of the validity of this tool at educational aspects.

It has been suggested that the use of iPad as a new technology tool can be conducted in multiple ways in support of education among students inside classrooms (Beschorner \& Hutchison, 2013). Furthermore, the iPad contributes to improved many educational aspects. Also, these aspects needed to achieve success among school students (Cubelic \& Larwin, 2014; Cumming et al., 2014; and Reichenberg, 2014).

There are many features, which make the iPad an excellent education tool inside classrooms such as sound, touch screen, colors, and animations. Many researchers believe that iPad is considered a powerful tool for engagement in education (Spencer et al., 2013).
Moreover, Clark \& Luckin (2013); Kitchner (2012); Fagan \& Coutts (2012) found that iPad contributes to increasing the effectiveness of delivery in the classroom. Moreover, Clark (2014) confirmed that the iPad helps to facilitate seamless learning.

It is essential to know that iPad is different from other educational tools; the iPad can use a game, knowledge sources, camera, education, YouTube, social media, explore, and others else. However, it is imperative to care when our children use in their life. Thus, the current paper will review related researches to the $\mathrm{iPad}$ as an educational technology tool inside classrooms. Besides, this paper will be discussed the aims of the present paper, which will be in the next paragraph.

Hence, The aims of this paper are to (i) review the literature on $\mathrm{iPad}$ as a new educational technology tool inside classrooms; (ii) examine the educational aspects which it was done through using this tool; (iii) investigate the level of effectiveness to iPad as a new educational technology tool inside classrooms, and (iv) critical evaluation about the positive and negative indicates which based on previous studies will be mentioned and discussed iPad. 
International Journal of Childhood, Counselling, \& Special Education (CCSE), Volume1, Issue: 1 , September: 2020, pp.1-10

\section{IPad as an educational tool}

According to Johnson (2013); Kardell (2013); Schmitz (2014), the studies that addressed the iPad in education are increased since 2010. Some educational features that make the iPad an excellent educational tool will be reported below:

Amendments to the Texts: this feature is considered necessary in the education process; students can put the highlighting at the texts and can put amending texts. This feature help students to be more efficient and effective inside classrooms (Mossberg, 2010).

Ease of Connection to the Internet in the Classroom: according to Clark \& Luckin (2013) and Kennedy (2011), students can access to internet resources this feature make the education process a facilitates.

Developing Social Skills for Students: iPad has an effect on the social skills of students, Henderson and Yeow (2012) reported that students engage with social media apps. Further, Clark and Luckin (2013) confirmed that the iPad possesses many techniques at education that help and support students inside the classroom, such as presentation, a quick Internet search for topics, and brainstorming.
Speed and ease of communication between school and Parents: The major important feature in the iPad is the possibility of support from Parents. Where Fagan and Coutts (2012) found iPad contribute to increasing speed and ease of communication between school and parents, the feedback is essential in the education process as well as daily follow-up.

The effectiveness of iPad in education

Linskens (2013) and Van der Meer et al. (2015) provided proof and evidence to iPad effectiveness in various aspects of the educational process, for example, the multifunctional capability of the iPad has wide-ranging potential for use in education. Moreover, the iPad enhances learning experiences through many positive features. Furthermore, Van der Meer et al. (2015) reported that iPad as an educational tool enhance and support academic skills (e.g., picture/word matching).

Other evidence to the effectiveness of iPad at education where was provided by Nguyen, Barton \& Nguyen (2015), for instance, students used the Pocket Pond app to increase and improve sensory awareness by touching the screen, additionally to writing, students used Draw with Stars as a precursor. 
International Journal of Childhood, Counselling, \& Special Education (CCSE), Volume1, Issue: 1 , September: 2020, pp.1-10

Regarding the social context, where Brown et al. (2012) noticed the iPad is shown to be useful is in helping and support collaboration and productivity among students. As well as Ellis (2011) and Fagan \& Coutts (2012) observed that students collaborated with friends and peers on global topics that involved a realworld experience, then, students will be brought out of a sense of isolation.

\section{Review of literature of iPad}

Through a review of the literature of $\mathrm{iPad}$, the studies that addressed the iPad as an educational technology tool were conducted and carried out in two educational aspects: Literacy (reading and writing) and Mathematics. The current study will discuss the educational aspects which the iPad was conducted inside classrooms.

IPad and literacy (reading and writing):

Most studies that addressed iPad in the classroom have focused on literacy (e.g., Beschorner \& Hutchison, 2013; Hatherly and Chapman, 2013; Neumann \& Neumann, 2014; Oladunjoye, 2013; Reynolds-Blankeship, 2013). Those studies have indicated that the use of apps that support literacy skills (reading and writing) were allowed students to enhance the learning process.

In the study of Neumann and Neumann (2014), they found those
iPad apps to learn literacy (reading and writing) among students are based on social constructivism. In detail, this process will be achieved on the iPad by providing the exposure of visually appealing app icons as well as the symbols. Furthermore, this process will give students the understanding and expectation from a young age that the symbols have meaning additionally, can be "read." Moreover, this understanding and hope are used to decode the alphabets with helping others, such as adults who would be knowledgeable (Neumann and Neumann, 2014).

Other studies (Beschorner \& Hutchison, 2013; Hatherly \& Chapman, 2013; Oladunjoye, 2013) were explained that the application of touch-screens makes literacy learning (reading and writing skills) engaging. Then, the iPad will become an ideal tool in school, and kindergarten through the massive interaction possibilities attracts students to apps. The learning through linking the image and letter directly, then, this process led to speeding up the process in literacy (reading and writing skills) and education.

Similarly, the study of Muir (2012) also confirms that the use of iPad inside classrooms led to increasing students' literacy skills. Moreover, He reported that the use 
International Journal of Childhood, Counselling, \& Special Education (CCSE), Volume1, Issue: 1 , September: 2020, pp.1-10

of apps of fundamental literacy skills and concepts (reading and writing) were motivating and interactive among students. Also, he focused on the use of apps, which help students to advance in reading and writing assessments, as well as he compared between students that using iPad in literacy skills and who did not, he found that student's performance who is using iPad is outperformed in literacy skills (Muir, 2012). Furthermore, Richardson (2010) pointed out that the iPad allows the students to use a hand-held electronic device to navigate a book that helps to improve the reading skills, and gives the students a definition of words to understand the text; this will help teachers to personalize teaching.

More detailed, some studies, such as Bevan (2012), was explicitly conducted in Vocabulary. The results showed that students using iPad superiority over the rest of the students. Another study was conducted by Wang, Teng, and Chen (2015), the researchers also studied English Vocabulary Learning facilitation through using the iPad. The results confirmed increased learning motivation in the classroom by using the iPad.

As well as the study of Kirk (2011) studied reading skills, the students using iPad recorded themselves reading. Then both teacher and student listened to the recordings. Then the teacher corrects the errors in the readings through exercise repeated. In addition, Kirk reporting that students after reading and recording, the student's reading was clear and understandable.

\section{IPad and Mathematics:}

The studies of this aspect (Mathematics) were focused on students' feelings toward mathematics such as Larkin and Jorgensen (2015), the results of this study found that the students were comfortable through using the iPads in classrooms to record a video, as approximately $64 \%$ of the students did so. This result gives evidence of iPad to success at the educational process as a way of accessing student's thoughts about mathematics.

The previous studies that addressed iPad in education (for example Cubelic \& Larwin, 2014; Cubelic, 2013; Flewitt, Messer, \& Kucirkova, 2014; Reichenberg, 2014; Oladunjoye, 2013; Hatherly \& Chapman, 2013; Beschornerl \& Hutchson, 2013), were confirmed that the iPad achieves a high level of academic performance among students. Further, the researchers noted that iPad attracted students and reaches a high level of motivation because the iPad has many features which are attracted students to learn with enjoyment. This means that iPad was necessary at the educational process through 
International Journal of Childhood, Counselling, \& Special Education (CCSE), Volume1, Issue: 1 , September: 2020, pp.1-10

touch; a major aspect is an intrinsic motivation.

Therefore, the results of studies that used iPad's intervention at education were shown a high level of effectiveness inside classrooms.

\section{IPad and Creativity:}

The studies that addressed creativity were focused on developing the level of creativity and creative thinking among preschoolers such as Al-Zu'bi et al. (2017a); Al-Zu'bi et al. (2017b) AlZu'bi (2019), the results of the experiment found that the students were comfortable through using the iPad in creativity and motivation classrooms. This result gives evidence of iPad to success to develop personality aspects (such as creative thinking \& learning motivation) during the educational process.

Further, The previous studies that addressed iPad in personality aspects during the educational process (for example, Al-Zu'bi et al., 2017; Al-Zu'bi, 2019), were mentioned that the iPad grows the level of academic performance during the educational process. Furthermore, the researchers identified that the iPad attracts students and reaches a high level of motivation due to the iPad has many features which are attracted students to learn with enjoyment.
Hence, the results of studies that used iPad's intervention at education were shown a high level of effectiveness inside classrooms.

\section{Conclusion}

In summary, it is quite clear that the iPad is considered an educational technology tool that has a significant role in the educational process, especially among students. According to previous studies that addressed the iPad, all these studies are confirmed that the use of iPad in education was positive effectiveness through the increase and developed the level of academic performance in reading, writing, and mathematics. Hence, this is considered as an evidence of positive effects on iPad in education. However, in closer scrutiny of previous studies that use iPad in education is predominantly to improvement and helping to learn a literacy (reading and writing skills) such as (Cubelic \& Larwin, 2014; Cubelic, 2013; Flewitt, Messer, \& Kucirkova, 2014; Reichenberg, 2014; Oladunjoye, 2013; Hatherly \& Chapman, 2013; Beschornerl \& Hutchson, 2013).

According to the previous studies that addressed the iPad as an educational tool, it could be observed that those studies are limited to intervention on improving the level of literacy, including reading skills, writing skills, Vocabulary, English Language Learning, and Mathematics. 
International Journal of Childhood, Counselling, \& Special Education (CCSE), Volume1, Issue: 1 , September: 2020 , pp.1-10

However, the studies that used iPad to develop and increase the level of thinking skills such as critical thinking and creative thinking are still minimal, especially with reports that iPad supports creativity and creative thinking (Fagan \& Coutts, 2012). Therefore, this means that iPad is considered an ideal tool to learn and develop personality aspects that are deemed necessary at an educational process such as creativity, creative thinking, and critical thinking.

Similarly, there are reports from the study of Wang, Teng, and Chen (2015) that iPad affect to increase motivation among students. However, the studies that used the iPad to improve and develop the level of motivation are still minimal.

As a conclusion, according to reports above, the current study is recommended to conduct and carried out studies that use iPad as an intervention to develop and increase the level of creativity, creative thinking, critical thinking, motivation and learning motivation to make sure the effectiveness of iPad at these aspects.

\section{References}

Al-Zu'bi, M. A. A., Omar-Fauzee, M. S., \& Kaur, A. (2017a). The effect of iPad apps on creative thinking among preschoolers in Jordan. International Journal of
Multidisciplinary Education and Research, 2(4), 29-35.

Al-Zu'bi, M. A. A., Omar-Fauzee, M. S., \& Kaur, A. (2017b). The Relationship between Creative Thinking and Motivation to Learn Creative Thinking among PreSchoolers in Jordan. European Journal of Education Studies, 3(3), 426-442.

Al-Zu'bi, M. A. (2019). The Effects of Ipad Applications on Creative Thinking and Learning Motivation among Preschool Children in Jordan (Unpublish doctoral dissertation, Universiti Utara Malaysia UUM).

Beschorner, B., \& Hutchison, A. (2013). IPads as a Literacy Teaching Tool in Early Childhood. International Journal of Education in Mathematics, Science and Technology, 1(1), 16-24.

Bevan, E. (2012). How can ipads be used effectively as an instructional tool to improve literacy skills, specifically sight word vocabulary, in kindergarten? Retrieved from http://www.ed.psu.edu/educ/pds/teacher -inquiry/2012/Bevan- Inquiry 5-21-12.pdf

Brown, M., Castellano, J., Hughes, E., \& Worth, A. (2012). Integration of IPads into a Japanese university English language curriculum. The Jalt Call Journal, 8(3), 197-209.

https://doi.org/10.29140/jaltcall.v8n3.14 1

Cubelic, C. J. (2013). IPad 2 Applications and Emergent Literacy: 
International Journal of Childhood, Counselling, \& Special Education (CCSE), Volume1, Issue: 1 , September: 2020 , pp.1-10

Do They Have an Impact on the Acquisition of Early Literacy Skills? (Unpublished doctoral dissertation, Youngstown State University).

Cubelic, C., \& Larwin, K. (2014). The Use of iPad Technology in the Kindergarten Classroom: A QuasiExperimental Investigation of the Impact on Early Literacy Skills. Comprehensive Journal of Educational Research, 2(4), 47 - 59.

Cumming, T. M., Strnadová, I., \& Singh, S. (2014). IPads as instructional tools to enhance learning opportunities for students with developmental disabilities: An action research project. Action Research, 12(2), 151-176. https://doi.org/10.1177/1476750314525 480

Ellis, S. (2011). Teaching the future: How iPads are being used to engage learners with special needs. Screen Education, 63, 60-64.

Flewitt, R., Messer, D., \& Kucirkova, N. (2014). New directions for early literacy in a digital age: the iPad. Journal of Early Childhood Literacy. Advance online publication. 15(3), 289-310.

https://doi.org/10.1177/1468798414533 560

Hatherly, A., \& Chapman, B. (2013). Fostering motivation for literacy in early childhood education using iPads. Computers in New Zealand Schools: Learning, teaching, technology, 25(1-3), 138-151.
Henderson, S., \& Yeow, J. (2012, January). iPad in education: A case study of iPad adoption and use in a primary school. In System Science (HICSS), 2012 45th Hawaii International Conference on (pp. 7887). IEEE.

Kitchner, A. M. (2012). Integrating iPads into the Four-Year-Old Kindergarten Classroom (Unpublished doctoral dissertation, University of Wisconsin-Stout).

Fagan, T. \& Coutts, T. (2012). To iPad or not to iPad. Retrieved from http://www.coreed.org/sites/coreed.org/files/Fagan-Coutts-iPadresearch.pdf

Johnson, D. (2013). Implementing A one-to-one IPad Program in A secondary School (Unpublished doctoral dissertation, University of Nebraska at Omaha).

Kardell, S. (2013). Improving Writing Skills, Along With Student Attitude Toward Writing, in a Seventh Grade Classroom Through the Use of Specific iPad (Doctoral dissertation, Caldwell College).

Kennedy, M. (2011). Learning tools. American School \& University, 83(10), 16.

Kirk, A. (2011, January 10). Apple in the classroom: Students using iPods, iPads to improve reading, math. The Herald-Journal. Retrieved December 3, 2011 from http://news.hjnews.com/news/education 
International Journal of Childhood, Counselling, \& Special Education (CCSE), Volume1, Issue: 1 , September: 2020, pp.1-10

$\angle$ article 937f4736-1c7b-11e0-94f2-

001cc4c03286.html.

Larkin, K., \& Jorgensen, R. (2015). 'I Hate Maths: Why Do We Need to Do Maths?' Using iPad Video Diaries to Investigate Attitudes and Emotions Towards Mathematics in Year 3 and Year 6 Students. International Journal of Science and Mathematics Education. Advance online publication. https://doi.org/10.1007/s10763-0159621-x

Linskens, J. (2013). The impact of iPads on student engagement, motivation, and achievement and teacher effectiveness in the school district of north fond du lac topic paper. Retrieved from http://linskensportfolio.wikispaces.com/ Dissertation+Topic+Paper

Mossberg, W. (2010). Finding the best way to read books on an iPad. Wall Street Journal - Eastern Edition, pp. D1-D2.

Muir, M. (2012). IPad improves kindergarteners literacy scores. In Dalrymple. Retrieved May 21, 2012 from www.loopinsight.com.

Neumann, M. M., \& Neumann, D. L. (2014). Touch screen tablets and emergent literacy. Early Childhood Education Journal, 42(4), 231-239.

Nguyen, L., Barton, S. M., \& Nguyen, L. T. (2015). Ipads in higher education-hype and hope. British Journal of Educational Technology, 46(1), 190-203. https://doi.org/10.1111/bjet.12137
Nielsen, J. (2010). IPad usability: First findings from user testing. Retrieved from http://www.useit.com/alertbox/ipad.html

Oladunjoye, O. K. (2013). IPad and computer devices in preschool: A tool for literacy development among teachers and children in preschool (Unpublished masters theses, Stockholm Universitet).

Reichenberg, J. L. (2014). The use of iPads to facilitate growth in reading comprehension skills of second grade students (Unpublished doctoral dissertation, Liberty University).

Reynolds-Blankeship, T. (2013). An Action Research Study Investigating Children's Use of an IPad During Free Play in a Kindergarten Classroom: an Exploration of Teaching Pedagogy and Children's Learning, Social Interactions, and Digital Literacy (Unpublished doctoral dissertation, Texas Woman's University).

Schmitz, A. (2014). Two SingleSubject Experiments of An IPad Protocol When Training Special Education Professionals in Video Modeling (Unpublished master's thesis, The University of Wisconsin - Milwaukee).

Spencer, K. M., Coutts, T., Fagan, T., \& King, A. (2013). Connections, Diversity, Coherence: Three Vignettes Exploring Learning with iPads in Primary Schools. 
International Journal of Childhood, Counselling, \& Special Education (CCSE), Volume1, Issue: 1 , September: 2020 , pp.1-10

Computers in New Zealand Schools: Learning, teaching, technology, 25(13), 38-55.

Van der Meer, L., Achmadi, D., Cooijmans, M., Didden, R., Lancioni, G. E., O’Reilly, M. F., ... \& Sigafoos, J. (2015). An iPad-Based Intervention for Teaching Picture and Word Matching to a Student with ASD and Severe Communication Impairment. Journal of Developmental and Physical Disabilities, 27(1), 67-78. https://doi.org/10.1007/s10882-0149401-5

Wang, B. T., Teng, C. W., \& Chen, H. T. (2015). Using iPad to Facilitate English Vocabulary Learning. International Journal of Information and Education Technology, 5(2), 100-104.

https://doi.org/10.7763/ijiet.2015.v5.48

4 